\title{
Perbedaan Frekuensi Pemberian Enteral Feeding terhadap Toleransi Feeding dan Kadar Glukosa Darah
}

\author{
Dewi Siti Oktavianti ${ }^{*}$, Yulia ${ }^{2}$, Riri Maria ${ }^{3}$ \\ ${ }^{1}$ Program Studi Keperawatan STIKes PERTAMEDIKA, Jakarta, Indonesia \\ ${ }^{2,3}$ Fakultas Ilmu Keperawatan Universitas Indonesia, Depok, Indonesia \\ * oktaviantidewi1110@gmail.com
}

\begin{abstract}
Medical nutrition therapy is one of the interventions to provide sufficient nutrition and to optimize glycemic controls to fulfil the body metabolic needs. An Enteral Feeding is an alternative feeding method when there are obstacles to fulfill patients nutrition orally. The study aims to determine feeding tolerances and blood glucose controls in Type 2 diabetes mellitus patients with different Enteral Feeding frequencies-three and six times preserving. This research was a quasi-experimental design study involving 26 patients divided into 2 groups admitted in a hospital. The results showed that there was a statistically difference between the three times and six times enteral feeding with blood glucose $(p=0.005)$, meaning that the frequency of six times per 24 hours better glycemic control compared the frequency of three times per 24 hours. There was a difference between the frequency of enteral feeding six times and three times with feeding tolerance $(p=0.005)$, meaning that respondents with enteral feeding frequency of six times more tolerant of enteral feeding than respondents with enteral feeding frequency of three times per 24 hours. Results of this study will assist in controlling blood glucose by regulating the timing of feeding in patients with type 2 diabetes mellitus.
\end{abstract}

Keywords : blood glucose, enteral feeding, enteral feeding frequencies-three and six times per 24 hours, feeding tolerance, type 2 diabetes mellitus

\begin{abstract}
Abstrak
Terapi nutrisi medis merupakan salah satu intervensi untuk mengoptimalkan kontrol glikemik dan menyediakan kalori yang cukup untuk memenuhi kebutuhan metabolik. Pasien diabetes yang tidak dapat memenuhi kebutuhan gizinya melalui asupan makanan oral;,membutuhkan enteral feeding. Penelitian ini bertujuan untuk mengetahui perbedaan frekuensi pemberian enteral feeding sebanyak tiga kali dan enam kali secara bolus dengan toleransi feeding dan kadar glukosa darah pada pasien diabetes melitus tipe2. Penelitian ini menggunakan desain quasi experimental yang melibatkan 26 pasien di rumah sakit yang dibagi menjadi dua kelompok. Hasil penelitian menunjukan ada hubungan yang signifikan antara frekuensi pemberian enteral feeding dengan glukosa darah $(p: 0,005)$ artinya bahwa frekuensi pemberian enteral feeding enam kali menghasilkan kontrol glikemik yang lebih baik dibandingkan dengan pemberian enteral feeding dengan frekuensi tiga kali per $24 \mathrm{jam}$. Ada perbedaan yang signifikan antara frekuensi pemberian enteral feeding pada kelompok enam kali dan tiga kali terhadap toleransi feeding ( $p$ value: 0,005), artinya pasien dengan pemberian enteral feeding enam kali lebih toleran terhadap enteral feeding dibandingkan dengan pasien yang diberikan enteral feeding dengan frekuensi tiga kali per 24 jam. Hasil Penelitian ini akan membantu dalam mengontrol gula darah melalui pengaturan waktu pemberian nutrisi enteral pada pasien diabetes melitus tipe2.
\end{abstract}

Kata Kunci : diabetes melitus tipe 2, enteral feeding, frekuensi pemberian enteral feeding sebanyak tiga kali dan enam kali per 24 jam, glukosa darah, toleransi feeding

Jurnal Keperawatan Raflesia, Volume 3 Nomor 1, Mei 2021

ISSN: (p) 2656-6222, (e) 2657-1595 DOI 10.33088/jkr.v3i1.617

Available online: https://jurnal.poltekkes-kemenkes-bengkulu.ac.id/index.php/jkr 


\section{PENDAHULUAN}

Diabetes Melitus (DM) adalah sekelompok gejala gangguan metabolik yang ditandai dengan adanya hiperglikemia kronik, yang disebabkan oleh gangguan sekresi insulin, kerja insulin, atau keduanya (ADA, 2012). Terdapat empat jenis utama diabetes melitus yaitu : diabetes melitus tipe1 penyebabnya adalah rusaknya sel $\beta$ pankreas yang mengakibatkan kekurangan insulin yang absolut. Diabetes melitus tipe 2 terjadi akibat resistensi insulin dan merupakan kasus yang paling banyak terjadi hampir $85-95 \%$ dari kasus diabetes, dan diabetes tipe lain serta diabetes melitus gestasional yang terjadi saat kehamilan (Zheng et al., 2018)

Diperkirakan pada tahun 2030 lebih dari 346 juta orang diseluruh dunia akan mengalami diabetes melitus. Jumlah kasus diabetes melitus terbanyak di dunia yaitu di India yang mencapai lebih dari 32 juta jiwa serta diperkirakan terjadi peningkatan di tahun 2030 sebesar 79,4 juta jiwa (Shrivastava et al., 2013). Sedangkan di Indonesia, WHO memprediksikan bahwa jumlah orang dengan diabetes melitus akan terjadi peningkatan tahun 2000 dari 8,4 juta menjadi 21,3 juta di tahun 2030 (PERKENI, 2015). Menurut Hasil Riset Kesehatan Dasar tahun 2013 menunjukkan proporsi penyakit diabetes melitus yang diperoleh berdasarkan wawancara, meningkat hampir dua kali lipat yaitu sebesar 2,1\% dibandingkan pada tahun 2007 yaitu sebanyak 1,1\% (Badan Penelitian dan Pengembangan Kesehatan, 2013).

Masalah utama yang dihadapi oleh orang dengan diabetes melitus adalah hiperglikemia kronik yang dapat memicu timbulnya berbagai komplikasi. Komplikasi yang terjadi yaitu komplikasi mikrovaskuler dan makrovaskuler. Komplikasi yang paling banyak terjadi pada orang dengan diabetes tipe 2 adalah komplikasi mikrovaskuler, yang dibuktikan oleh hasil studi pada 66.726 orang dengan diabetes melitus tipe 2 menunjukkan bahwa sebanyak 53,5\% memiliki komplikasi mikrovaskuler dan 27,2\% memiliki komplikasi makrovaskuler (Litwak et al., 2013).

Upaya yang dapat dilakukan untuk mencegah, menghambat dan mengurangi komplikasi akibat diabetes melitus adalah dengan melakukan pengontrolan gula darah. Hal ini dibuktikan oleh hasil penelitian Deepa, Kiran, Gadwalkar (2014) bahwa kontrol gula darah yang intensif dapat mengurangi risiko retinopati diabetik (20\%), nefropati (37\%), neuropati (16\%), penyakit kardiovaskuler (26\%), penyakit cerevrovaskuler (8\%), dan penyakit pembuluh darah perifer $(11 \%)$ (Deepa et al., 2014). Hasil study population and baseline characteristics yang dilakukan pada 11.140 orang menunjukkan bahwa setiap peningkatan $1 \%$ glycated haemoglobin (HbA1C) berisiko meningkatkan $\quad 38 \% \quad$ penyakit makrovaskuler, $\quad 40 \% \quad$ penyakit mikrovaskuler, dan $38 \%$ menyebabkan kematian (Zoungas et al., 2012). Penatalaksanaan diabetes melitus untuk mengontrol gula darah adalah pemberian edukasi, pengaturan diet, exercise dan medikasi (PERKENI, 2015).

Terapi nutrisi medis merupakan salah satu intervensi untuk mengoptimalkan kontrol glikemik dan menyediakan kalori yang cukup untuk memenuhi kebutuhan metabolic (Gosmanov \& Umpierrez, 
2014). Hasil studi menyatakan pemberian terapi nutrisi medis dan obat hipoglikemik oral selama 12 minggu menunjukkan penurunan HbA1c sekitar 2,0\% pada diabetes (Barakatun Nisak et al., 2013). Salah satu manifestasi diabetes melitus pada gangguan serebrovaskular yaitu dapat mengakibatkan disfagia dan membutuhkan asupan nutrisi dari luar (Ojo, 2010). Enteral feeding dibutuhkan oleh pasien diabetes melitus untuk memenuhi asupan kebutuhan gizinya melalui oral (Ojo, 2015).

Enteral feeding pada pasien dengan diabetes melitus sama halnya pada pasien lain, berperan untuk memenuhi kebutuhan mikro dan makro nutrisi yang terdiri dari protein, karbohidrat, vitamin, dan mineral yang dapat mengurangi risiko malnutrisi (Ojo, 2015). Standard formulas enteral feeding oral atau tube mengandung tinggi karbohidrat, rendah lemk, dan rendah serat. Sedangkan formulasi nutrisi khusus untuk penderita diabetes melitus yang direkomendasikan oleh American Diabetes Association adalah Diabetes Spesific Formula (DSF). DSF mengandung rendah karbohidrat, tinggi serat, dan tinggi monounsaturated fatty acids (MUFAs) (Via \& Mechanick, 2011). Hasil penelitian tentang perbandingan konsumsi enteral feeding yang mengandung DSF dengan standard formulas pada pasien diabetes melitus, menunjukkan bahwa pada DSF hasil glukosa darah postprandial secara signifikan lebih rendah dibandingkan dengan Standard Formula (SF) (Buranapin et al., 2014).

Enteral feeding diberikan sesuai dengan status nutrisi, penyakit primer, berat badan, usia pasien, keadaan saluran gastrointestinal, dan alat akses nutrisi enteral (Campos \& MacHado, 2012). Penelitian yang dilakukan pada 40 pasien trauma kepala dengan enteral feeding yang terbagi dua kelompok yaitu kelompok metode continue serta metode intermitten, menunjukkan tidak ada perbedaan signifikan pada kadar gula darah sewaktu masing-masing kelompok (Maurya et al., 2011). Penelitian yang dilakukan terhadap 59 pasien yang di rawat di icu yang diberikan enteral feeding secara intermitten 6 kali pemberian, dimana pada hari pertama diberikan sebanyak $50 \%$, hari kedua $75 \%$, hari ketiga $100 \%$ dari total kebutuhan kalori, dan hasilnya menunjukkan tidak ada perbedaan signifikan pada pengukuran kadar gula darah sewaktu pada pengamatan hari pertama, hari kedua, dan hari ketiga (Hasir et al., 2014). Pasien diabetes dengan enteral feeding lebih berisiko mengalami hiperglikemia maupun hipoglikemia jika pemberian enteral feeding dengan NGT tidak dapat ditoleransi dengan baik (Via \& Mechanick, 2011). Makanan yang seimbang dan sesuai dengan kebutuhan kalori dan zat gizi masing-masing individu merupakan salah satu prinsip pengaturan makan pada diabetes (Mohammed et al., 2015). Selain itu pentingnya keteraturan makan dalam hal jadwal makan, jenis dan jumlah makanan, terutama orang dengan diabetes melitus yang menggunakan obat penurun glukosa darah atau insulin. Komposisi diet diabetes yang dianjurkan meliputi karbohidrat, protein, dan lemak. Asupan karbohidrat diabetes melitus dianjurkan adalah sebesar 45-65\% total kebutuhan energi dalam sehari. Makan tiga kali sehari untuk mendistribusikan asupan karbohidrat dalam sehari, serta dapat diberikan makanan selingan buah atau makanan lain sebagai bagian dari kebutuhan kalori sehari jika dibutuhkan 
(PERKENI, 2015).

Namun hasil penelitian prospektif dan observasional pada 64 pasien dengan enteral feeding dan terpasang nasogastric tube (NGT), didapatkan komplikasi sebagai berikut: dislodgement tube $(48,5 \%)$, gangguan elektrolit $(45,5 \%)$, hiperglikemia $(34,5 \%)$, diare $(32,8 \%)$, dan muntah (20,4\%) (Pancorbo-Hidalgo et al., 2001). Faktor-faktor yang dapat mempengaruhi kontrol glukosa pada pasien dengan enteral feeding yaitu terjadinya perubahan kecepatan absorpsi glukosa dan pengosongan lambung yang lambat pada pasien dalam keadaan kritis, serta ada atau tidak adanya status gastroparesis (Mabrey et al., 2015). Penelitian ini bertujuan untuk mengetahui perbedaan frekuensi pemberian enteral feeding sebanyak tiga kali dan enam kali terhadap toleransi feeding dan kadar glukosa darah.

\section{METODE}

Jenis Penelitian ini adalah kuantitatif dengan desain penelitian eksperimen semu tanpa control (quasi experiment without control). Rancangan penelitian ini adalah pre test and post test. Populasi penelitian yaitu pasien dengan riwayat diabetes melitus tipe 2 dan terpasang Naso Gastric Tube (NGT) di RSU wilayah Lebak dan wilayah Bekasi. Sampel pada penelitian ini adalah pasien di Ruang Rawat Inap kelas tiga. Teknik pengambilan sampel dalam penelitian ini dilakukan dengan menggunakan teknik consecutive sampling merupakan suatu teknik pengambilan sampel yang dilakukan dengan memilih individu yang memenuhi kriteria inklusi sampai jumlah sampel yang diinginkan terpenuhi (Dahlan, 2013). Pada penelitian ini terdapat dua kelompok yaitu kelompok yang diberikan enteral feeding dengan frekuensi enam kali dan kelompok yang diberikan enteral feeding tiga kali. Kedua kelompok sama-sama mendapatkan intervensi yaitu dilakukan pengukuran residu lambung dan gula darah. Sebelum responden diberikan makan pagi dan makan siang sesuai dengan diet di rumah sakit, pasien di ukur residu lambung nya terlebih dahulu kemudian memberikan makan sesuai diit rumah sakit. Dua jam setelah makan pagi dan makan siang, pasien dilakukan pengukuran glukosa darah post prandial dengan menggunakan glukometer yang sudah dikalibrasi. Setelah itu peneliti mencatat dan mengumpulkan semua data yang didapatkan dari responden selama penelitian berlangsung.

Jenis insulin yang digunakan responden penelitian ini adalah jenis insulin kerja cepat humulin dan kerja sedang actrapid. Terapi insulin diberikan pada pasien diabetes melitus apabila pengobatan yang dilakukan belum mencapai target glikemik. Regimen pemberian insulin meliputi fixed dose, sliding scale. Sliding scale adalah regimen pemberian insulin berdasarkan hasil pemeriksaan glukosa darah. Tetapi untuk jangka panjang, sliding scale tidak dianjurkan, segera beralih ke fixed dose serta tidak digunakan untuk menentukan dosis harian (PERKENI, 2015).

Besar sampel dihitung dengan rumus perkiraan besar sampel untuk data komparatif kategorik tidak berpasangan dengan hasil yaitu 26 orang responden. Kriteria inklusi pada penelitian adalah; 1) bersedia menjadi responden, 2) pasien dengan diabetes melitus tipe 2 yang terpasang NGT dan 3) pasien mendapatkan terapi insulin. Kriteria Ekslusi pada 
penelitian ini yaitu; 1) pasien menggunakan ventilator, 2) pasien mengalami diare sebelum pemberian enteral feeding, 3) pasien riwayat gastritis, 4) pasien dengan intoleransi susu, 7) pasien dengan stress ulcer. Instrument pada penelitian ini menggunakan lembar observasi yang berisi identitas diri responden dan lembar hasil observasi mengenai frekuensi enteral feeding, toleransi feeding, hasil pengukuraan glukosa darah postprandial.,

Pengolahan data melalui empat tahapan yaitu editing, coding, processing, dan cleaning. Analisa data penelitian meliputi analisis univariat untuk mengidentifikasi variabel independen maupun dependen. Selanjutnya, analisis bivariat dengan menggunakan uji chi square, untuk mengetahui adanya perbandingan antara frekuensi pemberian enteral feeding tiga kali dan enam kali dengan toleransi feeding dan kadar glukosa darah.

\section{HASIL}

Hasil penelitian ini adalah sebagai berikut :

\section{Tabel 1. Distribusi Responden Berdasarkan Toleransi Feeding Dan Kadar Glukosa Darah}

\begin{tabular}{|c|c|c|c|c|c|c|c|}
\hline \multirow[t]{2}{*}{ Variabel } & \multirow[t]{2}{*}{$\begin{array}{l}\text { Kate- } \\
\text { gori }\end{array}$} & \multicolumn{3}{|c|}{$\begin{array}{c}\text { Kelompok } \\
\text { Enteral } \\
\text { Feeding 6x }\end{array}$} & \multicolumn{2}{|c|}{$\begin{array}{l}\text { Kelompok } \\
\text { Enteral } \\
\text { Feeding } \\
3 \mathrm{x}\end{array}$} & \multirow{2}{*}{$\begin{array}{c}\text { Total } \\
\\
\% \\
\end{array}$} \\
\hline & & $\mathbf{n}$ & $\%$ & $\mathbf{n}$ & $\%$ & $\mathbf{n}$ & \\
\hline \multirow{2}{*}{$\begin{array}{l}\text { Toleransi } \\
\text { Feeding }\end{array}$} & Toleran & 12 & 92,3 & 2 & 15,4 & 14 & 53,85 \\
\hline & $\begin{array}{l}\text { Tidak } \\
\text { Toleran } \\
\end{array}$ & 1 & 7,7 & $\begin{array}{l}1 \\
1 \\
\end{array}$ & 84,6 & 12 & 46,15 \\
\hline \multirow{2}{*}{$\begin{array}{l}\text { Kadar } \\
\text { Glukosa } \\
\text { Darah }\end{array}$} & Normal & 12 & 92,3 & 3 & 23,1 & 15 & 57,7 \\
\hline & $\begin{array}{l}\text { Tidak } \\
\text { Normal } \\
\end{array}$ & 1 & 7,7 & $\begin{array}{l}1 \\
0 \\
\end{array}$ & 76,9 & 11 & 42,3 \\
\hline
\end{tabular}

Berdasarkan tabel 1 didapatkan bahwa sebanyak $92,3 \%$ pada kelompok enteral feeding enam kali lebih toleran terhadap enteral feeding dan memiliki kadar glukosa darah post prandial normal.

Tabel 2. Perbedaan antara Frekuensi Pemberian Enteral Feeding Pada Kelompok Tiga Kali dan Enam Kali Terhadap Toleransi Feeding

\begin{tabular}{|c|c|c|c|c|c|c|c|}
\hline \multirow{3}{*}{ Variabel } & \multicolumn{4}{|c|}{ Toleransi Feeding } & \multirow{3}{*}{$\mathrm{f}$} & \multirow{3}{*}{$\%$} & \multirow{3}{*}{$\begin{array}{c}p \\
\text { Value }\end{array}$} \\
\hline & \multicolumn{2}{|c|}{ Toleran } & \multicolumn{2}{|c|}{$\begin{array}{c}\text { Tidak } \\
\text { toleran }\end{array}$} & & & \\
\hline & $\mathbf{n}$ & $\%$ & n & $\%$ & & & \\
\hline \multicolumn{8}{|l|}{ Frekuensi } \\
\hline $6 x$ & 12 & 92,3 & 1 & 7,7 & 13 & 100 & \\
\hline $3 x$ & 2 & 15,4 & 11 & 84,6 & 13 & 100 & 0.005 \\
\hline Jumlah & 14 & & 12 & & 26 & & \\
\hline
\end{tabular}

Berdasarkan tabel 2 diketahui 92,3\% responden yang diberikan enteral feeding dengan frekuensi enam kali per 24 jam dan toleran terhadap enteral feeding yang diberikan, sedangkan sebanyak 15,4\% yang diberikan enteral feeding dengan frekuensi tiga kali per 24 jam yang toleran 
terhadap enteral feeding, dengan nilai $\mathrm{p}$ 0.005 artinya ada perbedaan yang signifikan antara frekuensi pemberian enteral feeding pada kelompok tiga kali dan enam kali terhadap toleransi feeding.

Tabel 3. Perbedaan antara Frekuensi Pemberian Enteral Feeding Pada Kelompok Tiga Kali dan Enam Kali Terhadap Kadar glukosa darah

\begin{tabular}{|c|c|c|c|c|c|c|c|}
\hline \multirow{3}{*}{ Variabel } & \multicolumn{4}{|c|}{ Glukosa darah } & \multirow{3}{*}{$\mathrm{f}$} & \multirow{3}{*}{$\%$} & \multirow{3}{*}{$\begin{array}{c}p \\
\text { Value }\end{array}$} \\
\hline & \multicolumn{2}{|c|}{ normal } & \multicolumn{2}{|c|}{$\begin{array}{c}\text { Tidak } \\
\text { normal }\end{array}$} & & & \\
\hline & $\mathrm{n}$ & $\%$ & $\mathrm{n}$ & $\%$ & & & \\
\hline \multicolumn{8}{|l|}{ Frekuensi } \\
\hline $6 x$ & 12 & 92,3 & 1 & 7,7 & 13 & 100 & \\
\hline $3 x$ & 3 & 15,4 & 10 & 84,6 & 13 & 100 & 0.005 \\
\hline Jumlah & 15 & & 11 & & 26 & & \\
\hline
\end{tabular}

Berdasarkan pada tabel 3 diketahui 92,3\% responden yang diberikan enteral feeding dengan frekuensi enam kali per 24 jam memiliki glukosa darah normal, sedangkan sebanyak 3 responden $(23,1 \%)$ yang diberikan diberikan enteral feeding dengan frekuensi tiga kali per 24 jam dan memiliki glukosa darah normal. Hasil analisis data bivariat didapatkan ada perbedaan yang signifikan antara frekuensi pemberian enteral feeding pada kelompok tiga kali dan enam kali dengan kadar glukosa darah ( $p$ value: 0,005 ).

\section{PEMBAHASAN}

Berdasarkan analisis tabel 1 tentang distribusi responden berdasarkan toleransi feeding dan kadar glukosa darah; menunjukkan bahwa pada kelompok enteral feeding enam kali yang toleran terhadap enteral feeding sebanyak 12 orang $(92,3 \%)$ dan yang tidak toleran sebanyak satu orang $(7,7 \%)$. Sedangkan kelompok enteral feeding tiga kali yang toleran terhadap enteral feeding sebanyak dua orang $(15,4 \%)$ dan yang tidak toleran sebanyak 11 orang $(84,6 \%)$. Pengukuran efektifitas pemberian enteral feeding dapat dilihat dari toleransi feeding. Toleransi terhadap pemberian enteral feeding dapat dilihat dari nilai residu lambung atau Gasric Residual Volume (GRV), adanya distensi abdomen, mual \& muntah, dan diare (Metheny et al., 2012). Pemberian enteral feeding tiga kali sehari dengan metode bolus menyebabkan secara cepat masuk ke lambung dan terisi penuh. Pengosongan lambung dan motilitas menjadi lambat disebabkan oleh isi lambung banyak, sehingga terjadi peningkatan residu lambung. Semakin besar isi makanan dalam lambung, maka semakin lambat pengosongan dalam lambung, sehingga mudah mengalami muntah $(28,3 \%)$ (Whelan \& Schneider, 2011). Selain itu hasil penelitian pada pasien yang diberikan nutrisi dengan metode bolus secara bertahap dengan frekuensi enam kali sehari menyebabkan lambung tidak terisi penuh dan lebih mudah mencerna makanan dan pengosongan lambung lebih cepat, dan dapat meminimalkan residu lambung sehingga dapat mengurangi risiko aspirasi (Ichimaru \& Amagai, 2015).

Penilaian keberhasilan dalam pengelolaan diabetes didapatkan dari hasil pengukuran glukosa darah, HbA1C, profil lipid, tekanan darah,dan kualitas hidup pasien yang baik. yaitu melakukan pengukuran kadar glukosa darah. Pemeriksaan glukosa darah dapat dilakukan saat pasien puasa, sebelum pasien mengkonsumsi makanan, dan dua jam setelah pasien mengkonsumsi makanan (PERKENI, 2015). Pada tabel 1 menyatakan bahwa pada kelompok enteral feeding enam kali sebanyak 92,3\% memiliki kadar glukosa darah postprandial 
(GDPP) normal, sedangkan pada kelompok enteral feeding tiga kali, hanya $23,2 \%$ responden mempunyai GDPP normal.

Pasien diabetes melitus dengan enteral feeding, monitor glukosa darah dilakukan dengan mengukur glukosa postprandial setiap empat sampai enam jam per hari. Nilai pengukuran normal glukosa darah yang direkomendasikan oleh IDF (2013) yaitu : untuk gula darah puasa normalnya < $110 \mathrm{mg} / \mathrm{dl}$, dan gula darah postprandial normalnya $<140 \mathrm{mg} / \mathrm{dl}(7.8 \mathrm{mmol} / \mathrm{l})$. Hasil penelitian menunjukkan bahwa pemeriksaan gula darah post prandial berperan penting dalam mengevaluasi respon insulin terhadap nutrisi yang dikonsumsi (Ahrén \& Foley, 2016).

Berdasarkan hasil uji statistik pada tabel 2 diketahui 12 responden (92,3\%) yang diberikan enteral feeding dengan frekuensi enam kali per 24 jam lebih toleran terhadap enteral feeding yang diberikan, dibandingkan dengan responden yang diberikan enteral feeding dengan frekuensi tiga kali per 24 jam terdapat dua responden $(15,4 \%)$ yang toleran terhadap enteral feeding. Hasil analisis data bivariat didapatkan ada perbedaan yang signifikan antara frekuensi pemberian enteral feeding pada kelompok tiga kali dan enam kali terhadap toleransi feeding ( $\mathrm{p}$ value : 0,005).

Nutrisi enteral (EN) sebagai pilihan utama dalam support nutrisi pada pasien dengan yang tidak dapat mempertahankan asupan makanan yang adekuat dan direkomendasikan oleh The American Society for Parenteral and Enteral Nutrition (ASPEN). Nutrisi enteral berperan dalam memelihara dan mempertahankan fungsi pencernaan, sebagai imunologik, mencegah organisme dalam usus menyerang tubuh, mengurangi sepsis dan hipermetabolik pada trauma (McMahon et al., 2012)

Proses pengosongan lambung yang lambat ditandai adanya peningkatan volume residu lambung. Residu lambung abnormal jika residu mencapai lebih dari 20\% dari total formula nutrisi yang diberikan, dua jam sebelum aspirasi lambung. Pada pemberian nutrisi dengan metode bolus, residu lambung yang dihasilkan rata-rata $30 \mathrm{ml}$ dengan pemberian diit nutrisi sebanyak 250ml diit cair. Residu lambung berupa susu yang tercerna adalah hasil dari pemberian enteral feeding secara bolus. Isi lambung penuh mengakibatkan pengosongan lambung dan motilitas menjadi lambat, sehingga residu lambung meningkat. Semakin besar volume makanan dalam lambung maka semakin lambat pengosongan dalam lambung (Nguyen et al., 2012). Sehingga pasien dengan pemberian enteral feeding tiga kali sehari lebih mudah mengalami tidak toleran terhadap enteral feeding dibandingkan dengan pasien yang diberikan enteral feeding enam kali sehari.

Berdasarkan hasil uji statistik pada tabel 3 didapatkan sebanyak 12 responden (92,3\%) yang diberikan enteral feeding dengan frekuensi enam kali per 24 jam memiliki glukosa darah postprandial normal, sedangkan sebanyak tiga responden $(23,1 \%)$ yang diberikan enteral feeding dengan frekuensi tiga kali per 24 jam memiliki glukosa darah postprandial normal. Hasil analisis data bivariat didapatkan ada perbedaan yang signifikan antara frekuensi pemberian enteral feeding pada kelompok tiga kali dan enam kali 
dengan kadar glukosa darah ( $p$ value: $0,005)$.

Sebuah penelitian yang dilakukan pada 59 pasien yang di rawat di ICU yang diberikan enteral feeding secara intermitten enam kali pemberian, dimana pada hari pertama diberikan sebanyak 50\% dari total kebutuhan kalori, hari kedua $75 \%$ dari total kebutuhan kalori, hari ketiga $100 \%$ dari total kebutuhan kalori, dan hasilnya menunjukkan tidak didapatkan perbedaan yang bermakna pada pengukuran kadar gula darah sewaktu pada pengamatan hari pertama, hari kedua, dan hari ketiga (Hasir et al., 2014).

Nutrisi enteral lebih baik diberikan secara berkala setiap tiga jam sebanyak enam kali pemberian agar glukosa darah terkontrol. Beberapa pasien dengan diabetes tipe 2 yang dirawat jalan dan rawat inap melaporkan bahwa kontrol glikemiknya lebih baik (glukosa postprandial dan puasa lebih rendah), penurunan $\mathrm{HbA} 1 \mathrm{C}$, dan kebutuhan insulin menurun dengan mengkonsumsi MUFA dibandingkan dengan mengkonsumsi $\mathrm{HCH}$ (high carbohydrate) formula (Gosmanov \& Umpierrez, 2014). Asosiasi Dietisien Indonesia menyatakan pemberian nutrisi yang tepat adalah dengan mengatur jangka waktu dalam pemberian nutrisi, seperti pemberian dengan frekuensi enam kali sehari, agar lambung lebih mudah mencerna makanan serta lambung kosong lebih cepat dan mengurangi resiko terjadinya aspirasi (Ahrén \& Foley, 2016).

\section{KESIMPULAN}

Hasil analisis terkait frekuensi pemberian enteral feeding dan kadar glukosa darah didapatkan bahwa ada hubungan yang signifikan antara frekuensi pemberian enteral feeding dengan glukosa darah ( $p$ value: 0.005 ), artinya bahwa frekuensi pemberian enteral feeding enam kali per 24 jam menghasilkan kontrol glikemik yang lebih baik dibandingkan dengan pemberian enteral feeding dengan frekuensi tiga kali per 24 jam.

Hasil analisis terkait frekuensi pemberian enteral feeding dan toleransi feeding yaitu terdapat perbedaan yang signifikan antara frekuensi pemberian enteral feeding pada kelompok enam kali dan tiga kali terhadap toleransi feeding ( $p$ value: 0,005 ), artinya pasien dengan pemberian enteral feeding enam kali per 24 jam lebih toleran terhadap enteral feeding dibandingkan dengan pasien yang diberikan enteral feeding dengan frekuensi tiga kali per 24 jam.

\section{DAFTAR PUSTAKA}

ADA. (2012). Standards of medical care in diabetes - 2012. Diabetes Care, 35(SUPPL.

$1)$. https://doi.org/10.2337/dc12-s011.

Ahrén, B., \& Foley, J. E. (2016). Improved glucose regulation in type 2 diabetic patients with DPP-4 inhibitors: focus on alpha and beta cell function and lipid metabolism. Diabetologia, 59(5), 907917.

Badan Penelitian dan Pengembangan Kesehatan. (2013). Riset Kesehatan Dasar (RISKESDAS) 2013. Laporan Nasional 2013, 1-384. https://doi.org/1 Desember 2013 
Barakatun Nisak, M. Y., Ruzita, A. T., Norimah, A. K., \& Nor Azmi, K. (2013). Medical nutrition therapy administered by a dietitian yields favourable diabetes outcomes in individual with type 2 diabetes mellitus. Medical Journal of Malaysia, 68(1), 18-23.

Buranapin, S., Siangruangsang, S., Chantapanich, V., \& Hengjeerajarus, N. (2014). The comparative study of diabetic specific formula and standard formula on postprandial plasma glucose control in type 2 DM patients. Journal of the Medical Association of Thailand= Chotmaihet Thangphaet, 97(6), 582-588.

Dahlan. (2013). Besar Sampel dan Cara Pengambilan Sampel.

Deepa, Kiran, \& Srikant R, G. (2014). Macrovascular and microvascular complications in type 2 diabetes patients. Indian Journal of Clinical Practice, 54(3), 229-237. https://doi.org/10.2337/dc06-2554.

Gosmanov, A. R., \& Umpierrez, G. E. (2014). Management of Hyperglycemia During Enteral and Parenteral Nutrition Therapy. 13(1), 155-162. https://doi.org/10.1007/s11892-0120335-y.

Hasir, J., Ahmad, M. R., Arif, S. K., \& Seweng, A. (2014). Pengaruh pemberian nutrisi enteral intermitten terhadap kadar gula darah sewaktu pada pasien cedera otak berat pascabedah. 4(1), 78-86.

Ichimaru, S., \& Amagai, T. (2015). Intermittent and Bolus Methods of Feeding in Critical Care. Diet and Nutrition in Critical Care, December, 795-806. https://doi.org/10.1007/978-14614-7836-2.

Litwak, L., Goh, S.-Y., Hussein, Z., Malek, R., Prusty, V., \& Khamseh, M. E. (2013). Prevalence of diabetes complications in people with type 2 diabetes mellitus and its association with baseline characteristics in the multinational A1chieve study. Diabetology \& Metabolic Syndrome, 5(1), 57. https://doi.org/10.1186/1758-5996-5-57.

Mabrey, M. E., Barton, A. B., Corsino, L., Freeman, S. B., Ellen, D., Bell, E. L., \& Setji, T. L. (2015). Managing enteral feedings: A health system approach. Hosp Pract (1995)., 43(2), 74-78. https://doi.org/10.1080/21548331.2015.1 022493.

Maurya, I., Pawar, M., Garg, R., Kaur, M., \& Sood, R. (2011). Comparison of respiratory quotient and resting energy expenditure in two regimens of enteral feeding - continuous vs. intermittent in head-injured critically ill patients. Saudi Journal of Anaesthesia, 5(2), 195-201. https://doi.org/10.4103/1658354X.82800.

Metheny, N. ., Millis, A., \& Stewart, B. J. (2012). Monitoring For Intolerance To Gastric Tube Feedings: A National Survey. 21(2), 33-41. https://doi.org/10.4037.ajcc2012647.

Mohammed, S., Islam, S., Niessen, L. W., Seissler, J., Ferrari, U., \& Biswas, T. (2015). Diabetes knowledge and glycemic control among patients with type 2 diabetes in Bangladesh. SpringerPlus.

https://doi.org/10.1186/s40064-0151103-7.

Nguyen, N. Q., Besanko, L. K., Burgstad, C., Bellon, M., Holloway, R. H., Chapman, M., Horowitz, M., \& Fraser, R. J. L. (2012). Delayed enteral feeding impairs intestinal carbohydrate absorption in critically ill patients*. Critical Care Medicine, 40(1), 50-54. https://doi.org/10.1097/CCM.0b013e318 $22 \mathrm{~d} 71 \mathrm{a} 6$.

Ojo, O. (2010). Managing patients on enterai feeding tubes in the community. November.

Ojo, O. (2015). Problems with use of a Foley catheter in enteral tube feeding. British Journal of Nursing, 23(September), 360364. https://doi.org/10.12968/bjon.2014.23.7.3 60. 
Pancorbo-Hidalgo, P. L., García-Fernandez, F. P., \& Ramírez-Pérez, C. (2001). Complications associated with enteral nutrition by nasogastric tube in an internal medicine unit. Journal of Clinical Nursing, $\quad 10(4), \quad 482-490$. https://doi.org/10.1046/j.13652702.2001.00498.x.

PERKENI. (2015). Pengelolaan dan pencegahan diabetes melitus tipe 2 di indonesia 2015.

Shrivastava, S. R., Shrivastava, P. S., \& Ramasamy, J. (2013). Role of self-care in management of diabetes mellitus. Journal of Diabetes and Metabolic Disorders, 12(1), 14. https://doi.org/10.1186/2251-6581-12-14.

Via, M. A., \& Mechanick, J. I. (2011). Inpatient Enteral and Parental Nutrition for Patients with Diabetes. 99-105. https://doi.org/10.1007/s11892-0100168-5.

Whelan, K., \& Schneider, S. M. (2011). Mechanisms, prevention, and management of diarrhea in enteral nutrition. Current Opinion in Gastroenterology, 27(2), 152-159. https://doi.org/10.1097/MOG.0b013e328 $34353 \mathrm{cb}$.

Zheng, Y., Ley, S. H., \& Hu, F. B. (2018). Global aetiology and epidemiology of type 2 diabetes mellitus and its complications. Nature Reviews Endocrinology, 14(2), 88.

Zoungas, S., Chalmers, J., Ninomiya, T., Li, Q., Cooper, M. E., Colagiuri, S., Fulcher, G., De Galan, B. E., Harrap, S., Hamet, P., Heller, S., MacMahon, S., Marre, M., Poulter, N., Travert, F., Patel, A., Neal, B., \& Woodward, M. (2012). Association of $\mathrm{HbA} 1 \mathrm{c}$ levels with vascular complications and death in patients with type 2 diabetes: Evidence of glycaemic thresholds. Diabetologia, 55(3), 636643. https://doi.org/10.1007/s00125-0112404-1. 